\title{
In vitro Anthelmintic Activity of Acanthus ilicifolius Leaves Extracts on Ascaridia galli and Pheretima posthuma
}

\author{
Dadang Irfan Husori ${ }^{1^{*}}$, Sumardi ${ }^{2}$, Heron Tarigan ${ }^{2}$, Selviani Gemasih ${ }^{2}$, Sri Rahayu Ningsih ${ }^{2}$ \\ ${ }^{1}$ Laboratory of Pharmacology, Faculty of Pharmacy, Universitas Sumatera Utara, Padang Bulan, Medan 20155, Indonesia. \\ ${ }^{2}$ Laboratory of Pharmaceutical, Faculty of Pharmacy, Tjut Nyak Dhien University, Medan, Indonesia.
}

\begin{tabular}{|c|c|}
\hline ARTICLE INFO & ABSTRACT \\
\hline Article history: & \multirow{5}{*}{$\begin{array}{l}\text { Parasitic worms in the chicken gastrointestinal tract are a chronic problem that becomes one of the causes of economic } \\
\text { losses in the poultry. The aim of the study was to evaluate the anthelmintic activity of Acanthus ilicifolius leaves } \\
\text { extract against Ascaridia galli and Pheretima posthuma. In vitro anthelmintic activity test was performed using } \\
3 \text { concentrations }(15,20 \text {, and } 25 \mathrm{mg} / \mathrm{ml} \text { ) of ethanol, aqueous, and n-hexane extract of Acanthus ilicifolius leaves } \\
\text { against Ascaridia galli and Pheretima posthuma. Pyrantel pamoate used as positive control, while the negative control } \\
\text { using normal saline and distilled water. The vehicle control using carboxymethyl cellulose. The time to paralyze and } \\
\text { time to death of worms were observed as anthelmintic activity parameter. The study also conducted phytochemical } \\
\text { screening of the extract. The ethanol, aqueous and n-hexane of Acanthus ilicifolius leaves extracts of } 15,20 \text {, and } 25 \\
\mathrm{mg} / \mathrm{ml} \text { concentration showed anthelmintic activity in Ascaridia galli and Pheretima posthuma. Anthelmintic activity } \\
\text { was dose-dependent manner. Meanwhile, the results of phytochemical screening showed the three types of extracts } \\
\text { contained secondary metabolites such as alkaloids, flavonoids, tannins, saponins and steroids. The ethanol, aqueous } \\
\text { and n-hexane extracts of Acanthus ilicifolius leaves possessed anthelmintic activity against worms Ascaridia galli and } \\
\text { Pheretima posthuma. }\end{array}$} \\
\hline Received on: $14 / 07 / 2017$ & \\
\hline Accepted on: 25/01/2018 & \\
\hline Available online: $27 / 02 / 2018$ & \\
\hline $\begin{array}{l}\text { Key words: } \\
\text { Anthelmintic, Acanthus } \\
\text { ilicifolius, Ascaridia galli, } \\
\text { Pheretima posthuma, pyran- } \\
\text { tel pamoate. }\end{array}$ & \\
\hline
\end{tabular}

\section{INTRODUCTION}

Parasitic worms in the gastrointestinal tract of chicken are a chronic problem that become one of the causes of economic losses in the poultry (Newbold et al., 2017), in addition to parasitic resistance caused by the use and misuse of drugs in the prevention and treatment of parasitic infections in farm animals (Douglas et al., 2015; Lawal et al., 2015). Ascaridia galli (A. galli) is parasitic worm with the highest prevalence in poultry that can lead to ascaridiasis disease (Naphade, 2014; Sahu and Sinha, 2016; Silva et al., 2015; Belete et al., 2016; Yousfi et al., 2013).

Acanthus ilicifolius (A. ilicifolius; Acanthaceae) is one of the plants traditionally used as an anthelmintic. Fruit, leaves, bark and roots of this plant have also been used for the treatment of asthma, diabetes, hepatitis, inflammation and arthritis (Mani et

\footnotetext{
${ }^{*}$ Corresponding Author

Dadang Irfan Husori, Laboratory of Pharmacology, Faculty of Pharmacy, Universitas Sumatera Utara, Padang Bulan, Medan 20155, Indonesia. E-mail:dadang@usu.ac.id; dihusori@gmail.com
}

al., 2008). While the leaves, roots, stems, and bark of A. ilicifolius have been reported to be potent antioxidants (Firdaus et al., 2013). A. ilicifolius in Indonesia is known as jeruju or daruju and grows wild in coastal areas (Quattrocchi, 2012). A. ilicifolius has been reported to contain secondary metabolites such as alkaloids, phenolic compounds, lignans, flavonoids, steroids and terpenoids (Wöstmann and Liebezeit, 2008; Ganesh and Vennila, 2011). This study was conducted to evaluate the in vitro anthelmintic activity of the ethanol, aqueous and n-hexane extracts from the leaves of A. ilicifolius against $A$. galli as worm parasites of chickens and Pheretima posthuma (P. posthuma) as a model of worms that infect the human digestive tract.

\section{MATERIALS AND METHODS}

\section{Preparation and preliminary phytochemical screening of the extracts}

The fresh leaves of A. ilicifolius were collected from Sungai Nipah Beach, District of Perbaungan, Serdang Bedagai, 
Sumatera Utara, Indonesia. The leaves were cleaned to remove unwanted material. The leaves were dried, then pulverized with a mechanical grinder. Seven hundred and fifty gram of pulverized leaves extracted with 8 liters of n-hexane using percolator apparatus. The extract was concentrated with rotary evaporator and freeze-dried to obtain a dry extract. Plant material residues were carried out the same extraction procedure using ethanol $96 \%$. Meanwhile, the aqueous extract of A. illicifolius leaves was prepared using decoction method. One hundred grams of powdered plant material was mixed with $1 \mathrm{~L}$ of distilled water and boiled for 60 minutes. The solution obtained was cooled, filtered, evaporated, and freeze-dried to obtain a dry extract. Phytochemical screening was performed on extracts to determine the secondary metabolites content (Harborne, 2012).

\section{Experimental animal}

A. galli adult worms were collected from the small intestine of infected chickens. Immediately after chicken slaughtered, the abdomen was opened and the material in the small intestine was taken and washed with normal saline for the collection of adult worms. Mean while, $P$. posthuma worms were collected from the damp soil and washed with normal saline. $P$. posthuma with $3-5 \mathrm{~cm}$ in length and $0.1-0.2 \mathrm{~cm}$ in width was used for anthelmintic activity test. The worms were identified in the Laboratory of Animal Taxonomy, Faculty of Mathematics and Natural Science, Universitas Sumatera Utara, Indonesia.

\section{In vitro anthelmintic activity evaluation}

Anthelmintic activity evaluation was performed with the adult worm motility test (Patilaya et al., 2017). A. galli and $P$. posthuma were placed in the petri dish containing $25 \mathrm{ml}$ of the test solution. Each extract of $A$. ilicifolius leaves consists of a series concentration of 15,20 , and $25 \mathrm{mg} / \mathrm{ml}$. Pyrantel pamoate at the 1.5 $\mathrm{mg} / \mathrm{ml}$ concentration was used as positive control, normal saline (A. galli) and distilled water ( $P$. posthuma) as negative control. Anthelmintic activity evaluation was carried out until the worm in the negative control group died. The tests were carried out with four replication. The time to paralyze and the time to death of worms were observed as anthelmintic activity parameters. The time for paralyze of the worms was achieved when there were no more movements unless the worm was plagued by the touch or immersed in $50^{\circ} \mathrm{C}$ of water. The time to death of worm was achieved if after stimulation given or immersed in water $50^{\circ} \mathrm{C}$, worms did not move. The experimental protocol was evaluated by Animal Research Ethics Committees (AREC), Universitas Sumatera Utara, Indonesia.

\section{Statistical analysis}

The results were analysed by comparing the time to paralyze and the time to death using ANOVA and Regression linear-test $(p<0.05)$. Statistical analysis was performed using SPSS 17 software programme.

\section{RESULTS AND DISCUSSION}

All of the extracts from A. ilicifolius leaves had anthelmintic activity on $A$. galli and $P$. posthuma which could be observed from the time to paralyze and the time to death of worms that were significantly different compared with the vehicle control (CMC) and negative controls (normal saline and distilled water). In vitro assay of the anthelmintic effect of plant extracts is often done due to the low cost and rapid. Moreover, this test is also able to measure anthelmintic activity in the phase of egg hatching, larval development, and parasite motility without interfering with the physiological function of the host animal (Kumarasingha et al., 2016).

\section{Anthelmintic activity on $\mathrm{A}$. galli}

Ethanol extract at the concentration of $25 \mathrm{mg} / \mathrm{ml}$ showed the shortest time to give paralysis effect on A. galli compared to the other extracts. The ethanol extract at the concentration of $25 \mathrm{mg} / \mathrm{ml}$ also had a faster time to death than the other extracts and the positive control (pyrantel pamoate $1.5 \mathrm{mg} / \mathrm{ml}$ ) as shown in Table 1. Anthelmintic activities possessed by three types of extracts were dose-dependent.

Table 1: The anthelmintic activity of $A$. ilicifolius leaves extract against $A$. galli.

\begin{tabular}{cccc}
\hline Treatments & $\begin{array}{c}\text { Conc. } \\
(\mathbf{m g} / \mathbf{m l})\end{array}$ & $\begin{array}{c}\text { Time to Paralysis } \\
(\mathbf{m i n})\end{array}$ & $\begin{array}{c}\text { Time to Death } \\
(\mathbf{m i n})\end{array}$ \\
\hline Ethanolic extract & 15 & $212.54 \pm 14.92^{\mathrm{a}}$ & $288.21 \pm 3.95^{\mathrm{a}}$ \\
& 20 & $157.31 \pm 6.37^{\mathrm{b}}$ & $203.22 \pm 8.41^{\mathrm{b}}$ \\
& 25 & $96.26 \pm 4.98^{\mathrm{c}}$ & $139.32 \pm 4.67^{\mathrm{c}}$ \\
Aqueous extract & 15 & $234.66 \pm 7.94^{\mathrm{a}}$ & $276.02 \pm 9.01^{\mathrm{a}}$ \\
& 20 & $171.29 \pm 4.43^{\mathrm{b}}$ & $222.41 \pm 7.76^{\mathrm{b}}$ \\
& 25 & $114.83 \pm 3.50^{\mathrm{c}}$ & $162.78 \pm 6.01^{\mathrm{c}}$ \\
n-Hexane extract & 15 & $234.36 \pm 2.71^{\mathrm{a}}$ & $264.23 \pm 12.03^{\mathrm{a}}$ \\
& 20 & $173.88 \pm 7.10^{\mathrm{b}}$ & $219.72 \pm 8.06^{\mathrm{b}}$ \\
Pyrantel Pamoate & 1.5 & $106.59 \pm 4.66^{\mathrm{c}}$ & $145.26 \pm 4.16^{\mathrm{c}}$ \\
CMC & 5 & $1,478.99 \pm 19.02^{\mathrm{d}}$ & $1,570.41 \pm 13.83^{\mathrm{d}}$ \\
$\mathrm{NaCl}$ & $0.9 \%$ & $1,632.13 \pm 3.26^{\mathrm{c}}$ & $1,746.19 \pm 5.30^{\mathrm{c}}$ \\
\hline
\end{tabular}

Different letters are significantly showed different anthelmintic activity ( $p$-value $<0.05$ )

The athelmintic effect was depend to the phytochemical constituent present in each extract. These results may be attributed to the content of polyphenol compounds which were higher in ethanolic extract compared to aqueous and n-hexane extracts. Ethanol solvent had better characteristics in penetrating cell walls, causing the release of high concentrations of polyphenol from plant materials (Wang, 2010). The n-hexane had low penetration on the plant cell wall. While the low anthelmintic activity of the aqueous extract against $A$. galli worm may be resulted from the activity of the polyphenol oxidase enzyme which is able to reduce polyphenols levels in the aqueous extract, whereas in ethanol solvent, this enzyme is inactive. The extraction process also used heat that degraded the active compounds. Several studies had also reported that higher flavonoid compounds were detected when extracted using $70 \%$ ethanol which has higher polarity than pure ethanol (Bimakr, 2011).

\section{Anthelmintic activity on $P$. posthuma}

The anthelmintic activity test on $P$. posthuma showed that aqueous extract at the concentration of $25 \mathrm{mg} / \mathrm{ml}$ had the time 
to paralyze and the time to death of worms faster than the other extracts. All extracts had time to paralyze and time to death of worm more rapidly than the positive control pyrantel pamoate at $1.5 \mathrm{mg} / \mathrm{ml}$ (Table 2). The anthelmintic activities produced by the three types of the extracts on P. posthuma were dose-dependent. In vitro anthelmintic evaluation used adult earthworms ( $P$. posthuma) due to the anatomical structures and physiological similarities with round worm parasite of human gastrointestinal tract, therefore it can be used for initial evaluation of anthelmintic activity (Aziz et al., 2014).

Table 2: The anthelmintic activity of A. ilicifolius leaves extract on P. posthuma.

\begin{tabular}{cccc}
\hline Treatments & $\begin{array}{c}\text { Conc. } \\
(\mathbf{m g} / \mathbf{m l})\end{array}$ & $\begin{array}{c}\text { Time to Paralysis } \\
(\mathbf{m i n})\end{array}$ & $\begin{array}{c}\text { Time to Death } \\
(\mathbf{m i n})\end{array}$ \\
\hline Ethanolic extract & 15 & $11.17 \pm 0.12^{\mathrm{ab}}$ & $14.34 \pm 0.16^{\mathrm{ab}}$ \\
& 20 & $7.27 \pm 0.38^{\mathrm{ab}}$ & $10.75 \pm 0.26^{\mathrm{a}}$ \\
& 25 & $4.06 \pm 0.19^{\mathrm{a}}$ & $4.78 \pm 0.19^{\mathrm{a}}$ \\
Aqueous extract & 15 & $10.59 \pm 0.31^{\mathrm{ab}}$ & $13.19 \pm 0.34^{\mathrm{ab}}$ \\
& 20 & $8.48 \pm 0.14^{\mathrm{ab}}$ & $9.90 \pm 0.27^{\mathrm{a}}$ \\
n-Hexane extract & 25 & $2.65 \pm 0.30^{\mathrm{a}}$ & $3.77 \pm 0.24^{\mathrm{a}}$ \\
& 15 & $28.86 \pm 0.75^{\mathrm{b}}$ & $36.26 \pm 1.92^{\mathrm{b}}$ \\
Pyrantel Pamoate & 20 & $16.60 \pm 0.56^{\mathrm{ab}}$ & $19.34 \pm 0.53^{\mathrm{ab}}$ \\
CMC & 25 & $6.89 \pm 0.09^{\mathrm{a}}$ & $8.28 \pm 0.38^{\mathrm{a}}$ \\
Aquadest & 5 & $202.43 \pm 7.86^{\mathrm{c}}$ & $250.71 \pm 8.86^{\mathrm{c}}$ \\
& - & $493.02 \pm 3.77^{\mathrm{d}}$ & $534.90 \pm 4.64^{\mathrm{d}}$ \\
\hline
\end{tabular}

Different letters are significantly showed different anthelmintic activity ( $p$-value $<0.05)$.

Preliminary phytochemical screening showed that $A$. illicifolius leave extracts contained alkaloids, flavonoids, steroids, tannins and saponins. Each of these secondary metabolites has been reported to have an important role in causing anthelmintic activity.

Tannins have been reported to have mechanism of action in disrupting the production of energy through the uncoupling of oxidative phosphorylation (Sutar et al., 2010; Sharma et al., 2010). Another mechanism of tannin is the ability to bind with the free protein in the digestive tract of the host animal or a glycoprotein on the cuticle of the worms which causes death. Some reports indicate that tannins contained in the plant are able to increase the absorption of protein. This is obtained through the formation of protein complexes in the rumen, which then break down at the low $\mathrm{pH}$ in the small intestine. Increase absorption of the protein in the host animal showed a decrease in the nematode worm infection rates (Patel et al., 2010), while the direct action of tannin on the nematode cuticle occurs through the hydrogen bonding. This reaction causes skin stiffness, resulting in paralysis and the death of nematodes (Vidyadhar et al., 2010).

The phytochemical screening of the extracts also revealed the presence of saponins. Saponins have been reported to increase the membrane permeability and pores formation. Both actions are similar to anthelmintic praziquantel and toltrazuril (Wang et al., 2010). The alkaloids and steroids in the extracts provide the suppressive effect of sucrose transfer to the small intestine which can reduce glucose support for worms. These effects together with the antioxidant effects of flavonoids can reduce the production of nitrate to be used in protein synthesis (Cruz, 2008). Alkaloids are also thought to act in the central nervous system of worms and cause paralysis (Roy, 2010). Paralysis and death of worms may also due to the mucopolysaccharide membrane damage by saponins and tannins. This mucoid-shaped membrane is a mucilaginous builder that protects the surface and cord sivory muscles. The membrane damage will expose the outer layer and allow the penetration of the chemical content of the extract to enter the body of the worm (Mulla et al., 2010). These results indicated there was a potential of $A$. illicifolius leaves extract to be used as an alternative anthelmintic.

\section{CONCLUSION}

The present study concludes that the ethanolic, aqueous and n-hexane extract of $A$. illicifolius leaves possess significant anthelmintic activity against $A$. galli and $P$. posthuma. Further research is recommended to exploring the phytochemicals content that was responsible for the anthelmintic activity from of $A$. illicifolius leaves extract.

\section{FINANCIAL SUPPORT AND SPONSORSHIP}

Nil.

\section{CONFLICT OF INTERESTS}

There are no conflicts of interest.

\section{REFERENCES}

Aziz A, Sarwar Raju G, Das A, Ahmed J, Moghal MMR. Evaluation of In vitro Anthelmintic Activity, Total Phenolic Content and Cytotoxic Activity of Crinum latifolium L. (Family: Amaryllidaceae). Adv Pharm Bull, 2014; 4(1):15-9. doi:10.5681/apb.2014.003.

Govindasamy C, Kannan R. Pharmacognosy of mangrove plants in the system of unani medicine. Asian Pac J Trop Dis, 2012; 2(Suppl 1):S38-41.

Banshi Sharma B. Poultry Production, Management And Bio-Security Measures. The Journal of Agriculture and Environment, 2010; $11: 120-5$.

Belete A., Addis M., Ayele M. Review on Major Gastrointestinal Parasites that Affect Chickens. Journal of Biology, Agriculture and Healthcare, 2016; 6(11):11-21.

Bimakr M, Rahmana RA, Taipa FS, Ganjloo A, Salleha LM, Selamat J, Hamid A, Zaidul ISM. Comparison of different extraction methods for the extraction of major bioactive flavonoid compounds from spearmint (Menthaspicata L.) leaves. Food Bioprod Process, 2011; 89:67-72.

Cruz ASP. Anthelmintic effect of Solanumlycocarpum in mice infected with Aspiculuristetraptera. The journal of American Science, 2008; 4(3):75-9.

Douglas E., Cosby, Nelson A. Cox, Mark A. Harrison, Jeanna L. Wilson, R. Jeff Buhr, Paula J. Fedorka-Cray. Salmonella and antimicrobial resistance in broilers: A review. J Appl Poult Res, 2015; 24(3):408-26. doi: 10.3382/japr/pfv038.

Feven B, Biniam G, Debesai G, Atul K. Screening of crude extracts of medicinal plants used in Eritrean unorthodox medicine for anthelmintic activity. The Pharma Research, 2010; 4:133-7.

Firdaus M, Prihanto AA, Nurdiani R, Widodo N. Antioxidant and cytotoxic activity of Acanthus ilicifolius flower. Asian Pac J Trop Biomed, 2013; 3(1):17-21.

Ganesh S., Vennila JJ., Phytochemical Analysis of Acanthus illicifolius and Avicennia officinalis by GC-MS. Research Journal of Phyto- 
chemistry, 2011; 5(1):60-5.

Harborne JB. 2012. Phytochemical Methods: A Guide to Modern Techniques of Plant Analysis. New York: Springer Science \& Business Media.

Kumarasingha R, Karpe AV, Preston S, Yeo TC, Lim DSL, Tu CL, Luu J, Simpson KJ, Shaw JM, Gasser RB, Beale DJ, Morrison PD, Palombo EA, Boag PR. Metabolic profiling and in vitro assessment of anthelmintic fractions of Picria fel-terrae Lour. International Journal for Parasitology: Drugs and Drug Resistance, 2016; 6:171-8.

Lawal JR., Jajere SM., Geidam YA., Bello AM., Wakil Y., Mustapha M. Antiobiotic residues in edible poultry tissues and products in Nigeria: a potential public health hazard. International Journal of Animal and Veterinary Advances, 2015; 7(3):55-61.

Mani SKKT, Gorain B, Roy DK, Zothanpuia, Samanta SK, Pal M, Biswas P, Roy A, Adhikari D, Karmakar S, Sen T. Anti-inflammatory activity of Acanthus ilicifolius. J Ethnopharmacol, 2008; 120:7-12.

Mulla WA, Thorat VS, Patil RV, Burade KB. Anthelmintic activity of leaves of Alocasiaindica Linn. International Journal of PharmTech Research, 2010; 2(1):26-30.

Naphade ST. A survey on prevalence of helminth infection in Desi Poultry birds from Marthawada region of Maharastra, India. International Journal of Research in Biosciences, 2014; 3(1):13-8.

Newbold LK., Burthe SJ., Oliver AE., Gweon HS., Barnes CJ., Daunt F., van der Gast CJ. Helminth burden and ecological factors associated with alterations in wild host gastrointestinal microbiota. The ISME Journal, 2017; 11:663-75. doi:10.1038/ismej.2016.153.

Patel J, Kumar GS, Qureshi MS, Jena PK. Anthelmintic activity of ethanolic extract of whole plant of Eupatorium odoratum. International Journal of Phytomedicine, 2010; 2:127-32.

Patilaya P., Husori DI., Sumantri IB. The anthelmintic effects of ethanol extract of Curanga fel-terrae leaves on Ascaridia galli. Asian Journal of Pharmaceutical and Clinical Research, 2017; 10(3):117-9.

Quattrocchi U. 2012. CRC World Dictionary of Medicinal and Poisonous Plants: Common Names, Scientific Names, Eponyms, Synonyms and Etymology. New York: CRC Press.

Roy H. Preliminary phytochemical investigation and anthelmintic activity of Acanthospermumhispidum DC. Journal of Pharmaceutical Science and Technology, 2010; 2(5):217-21.

Sahu S, Sinha KP. Studies on the prevalence of helminthic in- fection in desi poultry birds from Darbhanga region of North Bihar, India International Journal of Fauna and Biological Studies, 2016; 3(3):87-90.

Sharma US, Sharma UK, Singh A, Sutar N, Singh PJ. In vitro anthelmintic activity of Murraya koenigii Linn. Leaves extracts. International Journal of Pharma and Bio Sciences, 2010; 1(3):1-4.

Silva, GS da, Romera, DM, Fonseca, LEC, \& Meireles, MV. Helminthic Parasites of Chickens (Gallus Domesticus) in Different Regions of São Paulo State, Brazil. Revista Brasileira de Ciência Avícola, 2016; 18(1):163-8. https://dx.doi.org/10.1590/18069061-2015-0122.

Sutar N, Garai R, Sharma US, Sharma UK. Anthelmintic activity of Platycladusorientalis leaves extract. International Journal of Parasitology Research, 2010; 2(2):1-3.

Vidyadhar S, Saidulu M, Gopal TK, Chamundeeswari D, Rao U, Banji D. In vitro anthelmintic activity of the whole plant of Enicostemmalittorale by using various extracts. International Journal of Applied Biology and Pharmaceutical Technology, 2010; 1(3):1119-25.

Wang GS, Han J, Zhao LW, Jiang DX, Liu YT, Liu XL. Anthelmintic activity of steroidal saponins from Paris polyphylla. Phytomedicine, $2010 ; 17: 1102-5$.

Wang GX. In vivo anthelmintic activity of five alkaloids from Macleaya microcarpa (Maxim) Fedde against Dactylogyrus intermedius in Carassiusauratus. Veterinary Parasitology, 2010; 171:305-13.

Wöstmann, R. Liebezeit, G. Chemical composition of the mangrove holly Acanthus ilicifolius (Acanthaceae). Senckenbergiana Maritime, 2008; 38:31-7. doi:10.1007/BF03043866.

Yousfi F., Senouci K., Medjoual I., Djellil H., Slimane TH. Gastrointestinal helminths in the local chicken Gallus gallus domesticus (Linnaeus, 1758) in traditional breeding of North Western Algeria. Biodiversity Journal, 2013; 4(1): 229-34.

How to cite this article:

Husori DI, Sumardi, Tarigan H, Gemasih S, Ningsih SR. In vitro Anthelmintic Activity of Acanthus ilicifolius Leaves Extracts on Ascaridia galli and Pheretima posthuma. J App Pharm Sci, 2018; 8(02): 164-167. 